\title{
Inositol 1,4,5-Triphosphate-induced Granule Secretion in Platelets \\ Evidence That the Activation of Phospholipase C Mediated by Platelet Thromboxane Receptors Involves a Guanine Nucleotide Binding Protein-dependent Mechanism Distinct from That of Thrombin
}

\author{
Lawrence F. Brass, Calvin C. Shaller, and Elizabeth J. Belmonte \\ Hematology-Oncology Section, Department of Medicine, and the Coagulation and Thrombosis Laboratory, Department of Pathology \\ and Laboratory Medicine, University of Pennsylvania, Philadelphia, Pennsylvania 19104
}

\begin{abstract}
Phosphoinositide hydrolysis in platelets stimulated by thrombin is thought to be regulated by a pertussis toxin-sensitive guanine nucleotide binding protein ( $G$ protein) referred to as $G_{p}$. The present studies examine the role of $G_{p}$ in platelet responses to the thromboxane $A_{2}$ analogue $U 46619$ and in the pathway by which the phosphoinositide hydrolysis product inositol 1,4,5triphosphate $\left(\mathrm{IP}_{\mathbf{3}}\right)$ causes secretion. In permeabilized platelets, U46619 caused phosphatidic acid formation and secretion, which were abolished by the $G$ protein inhibitor, guanosine $5^{\prime}-O$ - (2thiophosphate) (GDPBS). Unlike thrombin, however, U46619induced phosphoinositide hydrolysis was unaffected by pertussis toxin, and $U 46619$ was unable to inhibit the $\left[{ }^{32} P\right] A D P$ ribosylation of the $42-\mathrm{kD}$ pertussis toxin substrate in platelets. $\mathbf{I P}_{\mathbf{3}^{-}}$ induced secretion, which is known to depend upon intracellular Ca release and subsequent arachidonic acid metabolism, was also inhibited by GDP $\beta S$, as was Ca-induced secretion. These observations suggest $(a)$ that platelet thromboxane $A_{2}\left(T_{x} A_{2}\right)$ receptors are coupled to a toxin-resistant form of $\mathbf{G}_{\mathrm{p}}$ distinct from the one that is coupled to thrombin receptors, and $(b)$ that TxA $\mathbf{A}_{2}$-stimulated phosphoinositide hydrolysis may serve as a feedback mechanism by which stimuli for arachidonic acid release, such as $\mathrm{IP}_{3}$ and $\mathrm{Ca}$, amplify responses to agonists.
\end{abstract}

\section{Introduction}

The hydrolysis of phosphatidylinositol 4,5-bisphosphate $\left(\mathrm{PIP}_{2}\right)^{1}$ by phospholipase $\mathrm{C}$ is one of the earliest events known to occur when platelets are activated by agonists such as thrombin (14). This process produced two key mediators of further platelet activation: diacylglycerol and inositol 1,4,5-triphosphate $\left(\mathrm{IP}_{3}\right)$. Diacylglycerol has been shown to cause protein phosphorylation

Address reprint requests to Dr. Brass, Hematology-Oncology Section, Silverstein 7, Hospital of the University of Pennsylvania, 3400 Spruce Street, Philadelphia, PA 19104. 1986.

Received for publication 17 June 1986 and in revised form 9 December

1. Abbreviations used in this paper: $\mathrm{G}$ protein, guanine nucleotide binding protein; GDP $\beta S$, guanosine 5'-O-(2-thiophosphate); $\mathrm{G}_{i}$, guanine nucleotide binding protein that mediates inhibition of adenylate cyclase; $G_{p}$, guanine nucleotide binding protein that regulates phospholipase $\mathrm{C}$ activation: $\mathrm{Gpp}(\mathrm{NH}) \mathrm{p}$, guanyl-5'-yl imidodiphosphate; $\mathrm{IP}_{3}$, inositol 1,4,5triphosphate; $\mathrm{PIP}_{2}$, phosphatidylinositol 4,5-bisphosphate; $\mathrm{TxA}_{2}$, thromboxane $\mathrm{A}_{2}$.

J. Clin. Invest.

(c) The American Society for Clinical Investigation, Inc.

0021-9738/87/04/1269/07 \$1.00

Volume 79, April 1987, 1269-1275 and secretion and the exposure of fibrinogen receptors on the platelet surface, events thought to be mediated by protein kinase $C(5-7)$. In platelets that have been permeabilized with saponin, exogenous $\mathrm{IP}_{3}$ causes secretion, protein phosphorylation, fibrinogen receptor exposure, and aggregation (7-12). In this case, however, these events appear to be a consequence of the ability of $\mathrm{IP}_{3}$ to trigger the release of $\mathrm{Ca}$ sequestered within the plateletdense tubular system $(7,10,13-15)$. The evidence that supports this conclusion is as follows. First, in platelets permeabilized with saponin, physiologically relevant concentrations of $\mathrm{IP}_{3}$ cause both $\mathrm{Ca}$ release from the platelet dense tubular system and dense granule secretion. The dose-response curves for these two processes are essentially identical. Secondly, the addition of EGTA to the permeabilized platelets has no effect on $\mathrm{IP}_{3}$-induced $\mathrm{Ca}$ release, but completely inhibits $\mathrm{IP}_{3}$-induced secretion. Thirdly, in platelets permeabilized by voltage discharge, increases in the cytosolic free $\mathrm{Ca}$ concentration caused by manipulation of the extracellular $\mathrm{Ca}$ concentration also cause secretion (16-18).

One mechanism by which the Ca discharged by $\mathrm{IP}_{3}$ might stimulate secretion is by stimulating arachidonic acid release from phospholipids such as phosphatidylcholine. It has recently been shown using platelets permeabilized with saponin that $\mathrm{IP}_{3^{-}}$ induced secretion, protein phosphorylation, and platelet aggregation are inhibited by aspirin, suggesting that these processes are partially dependent upon the products of arachidonic acid metabolism such as thromboxane $\mathrm{A}_{2}\left(\mathrm{TxA}_{2}\right)(10-12,19)$. It has also been shown that $T x A_{2}$ analogues bind to specific receptors on the platelet surface (20) and stimulate phosphoinositide hydrolysis (21-23). Collectively, these observations suggest a model in which the $\mathrm{Ca}$ released from the platelet-dense tubular system by $\mathrm{IP}_{3}$ stimulates phospholipase $\mathrm{A}_{2}(24)$ leading to arachidonic acid release, thromboxane formation, and amplification of the original stimulus for phosphoinositide hydrolysis. If this hypothesis is correct, then the mechanism that couples phospholipase $\mathrm{C}$ activation to thromboxane receptor occupation plays an important role and is a potential site for the regulation of platelet activation. In the case of thrombin, recent evidence suggests that phosphoinositide hydrolysis is regulated by a guanine nucleotide binding protein ( $G$ protein) that is commonly referred to as $G_{p}$. Specifically, it has been shown that thrombin stimulates GTPase activity in platelets (e.g., 25), that the addition of GTP or nonhydrolyzable GTP analogues to permeabilized platelets causes phosphoinositide hydrolysis and $\mathrm{Ca}$ release and secretion $(16-18,26)$, and that inhibitors of $G$ protein function, such as guanosine $5^{\prime}-O$-(2-thiophosphate) (GDP $\left.\beta S\right)(27,28)$ and pertussis toxin, will inhibit platelet responses to thrombin (26). In a previous study from this laboratory (26), inhibition of thrombin by pertussis toxin was associated with the ADP ribosylation of a protein with an apparent molecular mass of $42 \mathrm{kD}$ that comigrates with the $\alpha$ subunit of $G_{i}$, the $G$ protein that mediates inhibition of adenylate cyclase. The extent of inhibition by per- 
tussis toxin of thrombin-stimulated phosphoinositide hydrolysis paralleled the inhibition of thrombin's ability to suppress prostacyclin ( $\mathrm{PGI}_{2}$ )-stimulated cyclic AMP (cAMP) formation and correlated with the extent of labeling of the $42-\mathrm{kD}$ protein.

With this background, the present studies were designed to address two aspects of the regulation of platelet activation: $(a)$ to determine whether $\mathrm{TxA}_{2}$-stimulated phosphoinositide hydrolysis in platelets is, like thrombin-stimulated phosphoinositide hydrolysis, mediated by a $G$ protein and, if so, to examine the properties of that $\mathrm{G}$ protein, and $(b)$ to determine whether $\mathrm{IP}_{3^{-}}$ stimulated arachidonic acid metabolism is able to amplify platelet responses to agonists by "feedback" activation of phosphoinositide hydrolysis.

\section{Methods}

Platelet preparation. Washed platelets were prepared from fresh human blood as previously described (8). In brief, the platelets were sedimented from platelet-rich plasma, washed once in buffer containing $140 \mathrm{mM}$ $\mathrm{NaCl}, 20 \mathrm{mM}$ Hepes, and $1 \mathrm{mM}$ EDTA, pH 7.1, and then resuspended in buffer containing $137 \mathrm{mM} \mathrm{NaCl}, 2.7 \mathrm{mM} \mathrm{KCl}, 1 \mathrm{mM} \mathrm{MgCl} 2,3.3$ $\mathrm{mM} \mathrm{NaH} \mathrm{PO}_{4}$, and $20 \mathrm{mM}$ Hepes, $\mathrm{pH}$ 7.4. The final cell count was adjusted to $1.4 \times 10^{9} / \mathrm{ml}$. For the studies of secretion, the platelets were loaded with $\left[{ }^{14} \mathrm{C}\right]$ serotonin (New England Nuclear, Boston, MA) by addition of the labeled compound to platelet-rich plasma (8). When noted, the platelet-rich plasma was also incubated with $1 \mathrm{mM}$ aspirin for 30 min to inhibit cyclooxygenase. In some experiments, successful inhibition of eicosanoid synthesis was confirmed by measuring arachidonic acidinduced platelet aggregation (8).

Serotonin release from saponin-treated platelets. The washed platelet suspension was diluted to one fourth of the original concentration using buffer containing $160 \mathrm{mM} \mathrm{KCl}, 5.3 \mathrm{mM} \mathrm{MgCl}, 3.3 \mathrm{mM} \mathrm{ATP}$, and 13.3 $\mathrm{mM}$ Hepes, $\mathrm{pH}$ 7.1. The free $\mathrm{Ca}$ concentration was adjusted by the addition of EGTA and/or $\mathrm{CaCl}_{2}$ and was either measured with a $\mathrm{Ca}$ electrode or calculated as previously described (29). Afterwards, the platelets were preincubated with saponin (13-15 $\mu \mathrm{g} / \mathrm{ml}$ ) for $1 \mathrm{~min}$ before the addition of an agonist. When indicated, GDP $\beta S$ was added at the same time as the saponin. The reaction was terminated after 3-10 min by sedimenting the platelets at $14,000 \mathrm{~g}$ for $3 \mathrm{~min}$ in an Eppendorf microcentrifuge (Brinkman Instruments, Westbury, NY). Serotonin release was quantitated by measuring ${ }^{14} \mathrm{C}$ in aliquots of the supernate.

Phosphatidic acid formation. Washed platelets were preincubated for $1 \mathrm{~min}$ with saponin $(15 \mu \mathrm{g} / \mathrm{ml})$, ATP $(0.5 \mathrm{mM})$, and $\sim 4 \mu \mathrm{Ci} / \mathrm{ml}$ of $\gamma_{-}{ }^{32} \mathrm{P}$-labeled ATP (sp act 10-40 Ci/mmol, New England Nuclear) before adding an agonist. The reaction was terminated after $3 \mathrm{~min}$ by the addition of chloroform/methanol and $\left[{ }^{32} \mathrm{P}\right]$ phosphatidic acid formation was detected by thin layer chromatography as previously described (6). Preliminary studies showed that phosphatidic acid formation in the saponintreated platelets was maximal within $60 \mathrm{~s}$ of the addition of thrombin and the amount of $\left[{ }^{32} \mathrm{P}\right]$ phosphatidic acid remained constant for at least $5 \mathrm{~min}$. In the studies that examined the effects of pertussis toxin on phosphatidic acid formation, the toxin and $0.2 \mathrm{mM}$ NADH were added to the platelet suspension at the same time as the saponin and the preincubation period increased to $5 \mathrm{~min}$.

Detection of pertussis toxin substrates. [ $\left.{ }^{32} \mathrm{P}\right] \mathrm{ADP}$ ribosylation was performed as previously described (26). Washed platelets $\left(3.5 \times 10^{8} / \mathrm{ml}\right)$ were incubated with saponin $(15 \mu \mathrm{g} / \mathrm{ml}), \mathrm{NAD}(0.2 \mathrm{mM}),\left[{ }^{32} \mathrm{P}\right] \mathrm{NAD}$ (sp act $25 \mathrm{Ci} / \mathrm{mmol}$, final concentration $70 \mu \mathrm{Ci} / \mathrm{ml}$, New England Nuclear), pertussis toxin (15 $\mu \mathrm{g} / \mathrm{ml}$, List Biologicals, Campbell, CA), and EGTA $(10 \mu \mathrm{M})$. When indicated, thrombin or $\mathrm{U} 46619$ was added before the saponin. At the end of the incubation period, the platelets were sedimented and then analyzed by one-dimensional polyacrylamide electrophoresis in the presence of sodium dodecylsulfate (26). Protein bands were identified using Coomasie blue stain, and ${ }^{32} \mathrm{P}$-labeled proteins were detected by autoradiography.

cAMP formation. cAMP formation was measured using a radioim- munoassay kit (New England Nuclear) after extracting aliquots of the platelet suspension with $6 \%$ trichloroacetic acid.

Other materials. $\mathrm{IP}_{3}, \mathrm{U} 46619$, and A23187 were obtained from Sigma Chemical Co. (St. Louis, MO). Gpp(NH)p and GDP $\beta S$ were obtained from Boehringer Mannheim (Indianapolis, IN). Pertussis toxin was obtained from List Biologicals. Purified human $\alpha$-thrombin was the gift of Dr. John Fenton II, Division of Laboratories and Research, New York State Department of Health, Albany, NY.

\section{Results}

G-protein interactions with platelet thromboxane receptors. Previous studies have demonstrated that $\mathrm{TxA}_{2} / \mathrm{PGH}_{2}$ analogues stimulate phosphoinositide hydrolysis $(21-23,30)$ and GTPase activity (31) in platelets. In order to determine whether these responses reflect the coupling of one or more $G$ proteins to platelet $\mathrm{TxA}_{2}$ receptors, we first examined the effects of the $G$ protein inhibitor GDP $\beta S$ on phosphoinositide hydrolysis and secretion in permeabilized platelets stimulated with the $\mathrm{TxA}_{2}$ analogue, U46619. In the studies shown in Fig. 1, saponin-treated platelets were stimulated with $10 \mu \mathrm{M}$ U46619 in the presence of various concentrations of GDP $\beta S$. Phosphoinositide hydrolysis was detected by measuring phosphatidic acid formation. In the absence of GDP $\beta S$, U46619 caused a 2.5-fold increase in phosphatidic acid formation. GDP $\beta S$ inhibited this increase in a concentration-dependent manner. Half-maximal inhibition required $\sim 40 \mu \mathrm{M}$ GDP $\beta S$, which is similar to the GDP $\beta S$ concentration required to inhibit thrombin-induced diacylglycerol formation and $\mathrm{PGI}_{2}$-stimulated cAMP formation in saponintreated platelets (26). GDP $\beta S$ also inhibited U46619-induced secretion (Fig. 2). At $1 \mu \mathrm{M}$ U46619, inhibition of secretion was also half-maximal at $\sim 40 \mu \mathrm{M}$ GDP $\beta S$ (not shown).

Pertussis toxin has no apparent effect on intact platelets. However, we have recently demonstrated that the addition of the toxin to platelets permeabilized with saponin results in the inhibition of thrombin-stimulated phosphoinositide hydrolysis and of thrombin's ability to suppress $\mathbf{P G I}_{2}$-stimulated cAMP formation (26). This suggests that both $G_{p}$ and $G_{i}$ are affected by the toxin. In order better to characterize the $\mathrm{G}$ proteins coupled to platelet $\mathrm{TxA}_{2}$ receptors, we measured U46619-induced phosphatidic acid formation in saponin-treated platelets preincubated with pertussis toxin. Under conditions in which thrombin-induced phosphatidic acid formation was inhibited by

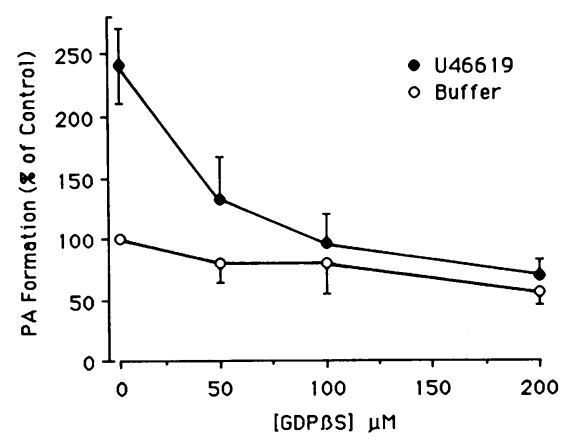

Figure 1. Phosphatidic acid formation in response to U46619. Washed platelets were incubated for $1 \mathrm{~min}$ with saponin, $\left[{ }^{32} \mathrm{P}\right] \mathrm{ATP}$, and GDP $\beta S$ (final concentration shown) before adding $10 \mu \mathrm{M}$ U46619 (closed circles) or solvent (open circles). The reaction was stopped 3 min later by the addition of chloroform/methanol and the $\left.{ }^{32} \mathrm{P}\right]$ phosphatidic acid isolated by thin-layer chromatography. The results shown are mean \pm standard error of the mean for four studies. 


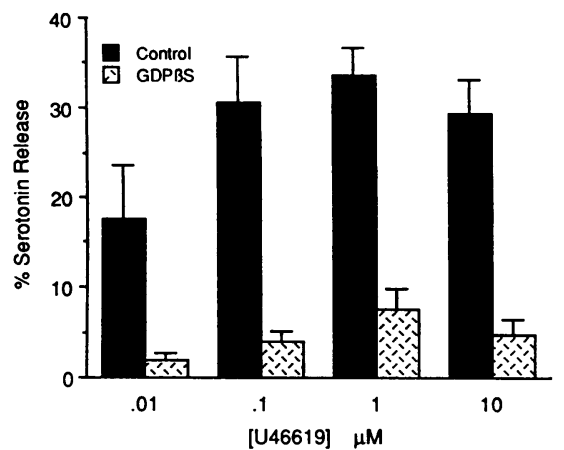

Figure 2. Secretion in response to U46619. U46619 at the final concentrations shown was added to washed platelets $2 \mathrm{~min}$ after the addition of (left) $3 \mathrm{mM}$ GDPBS or (right) $10 \mu \mathrm{M}$ pinane TxA $\mathrm{A}_{2}$. The results obtained in the presence of the inhibitors are shown in the hatched bars. Those obtained in the absence of the inhibitors are shown in the solid bars. The data shown are the mean of three studies of each type.

$\sim 60 \%$, the toxin had no effect on U46619-induced phosphatidic acid formation (Fig. 3, top). We also compared the ability of $\mathrm{U} 46619$ and thrombin to cause $\mathrm{G}_{\mathrm{i}}$-dependent inhibition of $\mathrm{PGI}_{2^{-}}$ stimulated cAMP formation. Intact platelets were preincubated with thrombin or $\mathrm{U} 46619$ before adding $1 \mu \mathrm{M} \mathrm{PGI}_{2}$. The formation of cAMP was followed for the next $2 \mathrm{~min}$. Thrombin suppressed cAMP formation by $>80 \%$. Under the same conditions, U46619 had no effect (Fig. 3, bottom).

These observations suggest that platelet $T \times A_{2}$ receptors are coupled to a toxin-insensitive form of $G_{p}$ and not coupled to $G_{i}$ at all. Incubation of permeabilized platelets with pertussin toxin and $\left[{ }^{32} \mathrm{P}\right] N A D$ results in the ADP ribosylation of a protein with an approximate molecular mass of $42 \mathrm{kD}$ (26). Preincubation of the platelets with thrombin abolishes the labeling of this protein, presumably because occupation of the thrombin receptor results in the dissociation of any coupled $G$ proteins into toxininsensitive subunits (see Discussion). Similar studies were performed with U46619. Under conditions in which thrombin abolished $\left[{ }^{32} \mathrm{P}\right] \mathrm{ADP}$ ribosylation of the $42-\mathrm{kD}$ protein, a concentration of U46619 which maximally stimulates phosphoinositide hydrolysis and secretion had no effect (Fig. 4). In agreement with the functional studies, this suggests that $\operatorname{TxA}_{2}$ receptors are not coupled to either toxin-sensitive $G$ protein.

Role of TxA $\mathrm{A}_{2}$-stimulated phosphoinositide hydrolysis in $\mathrm{IP}_{3}$ induced secretion. Several investigators have demonstrated that $\mathrm{IP}_{3}$-induced secretion in permeabilized platelets is blocked by inhibitors of cyclooxygenase such as aspirin or indomethacin (10-12), observations that we have confirmed (19). Aspirin has no effect on $\mathrm{Ca}$ release from the platelet-dense tubular system in response to $\mathrm{IP}_{3}(8)$. Therefore, in order to assess the contribution of $G$ protein-dependent phosphoinositide hydrolysis in

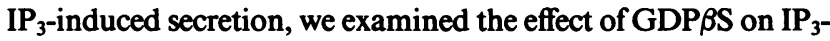
induced secretion and the effect of GDP $\beta S$ and aspirin on $\mathrm{Ca}$ induced secretion. In the studies shown in Fig. 5, $\mathrm{IP}_{3}$-induced secretion was measured at various GDP $\beta S$ concentrations. GDP $\beta S$ completely inhibited $\mathrm{IP}_{3}$-induced secretion. Inhibition was half-maximal at approximately the same GDP $\beta S$ concentration as that which inhibited U46619-induced phosphatidic acid formation and secretion. GDP $\beta$ S also inhibited Ca-induced secretion. The inhibition was not complete, but closely resembled the inhibition of Ca-induced secretion seen with aspirin (Fig. 6). In contrast to these results, we have previously shown that
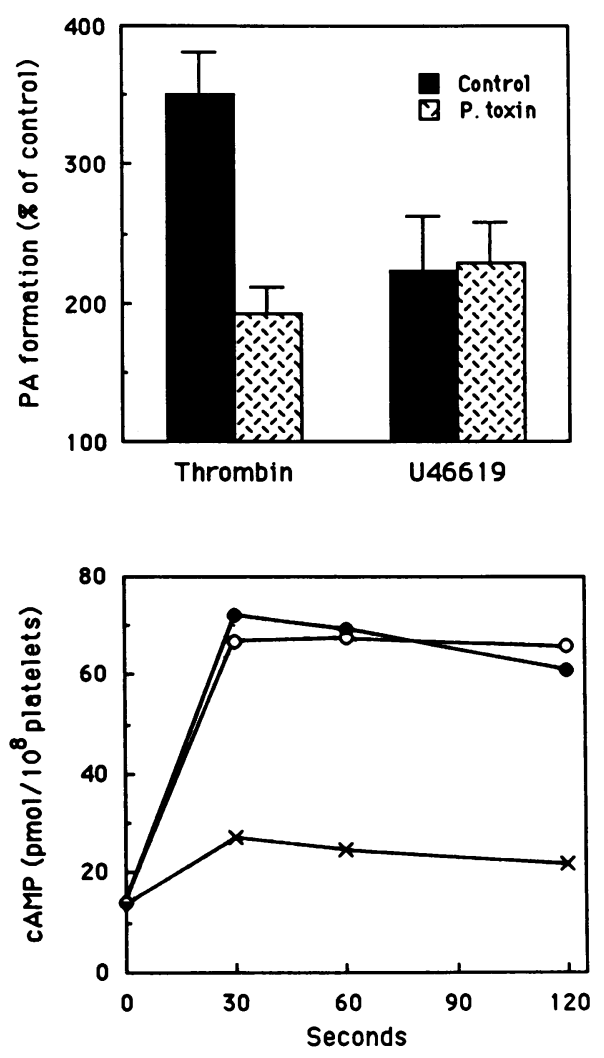

Figure 3. Comparisons between the effects of thrombin and U46619 on phosphatidic acid and CAMP formation. In the studies shown in the upper half of the figure, washed platelets were incubated for $5 \mathrm{~min}$ with saponin, $0.5 \mathrm{mM}\left[{ }^{32} \mathrm{P}\right] \mathrm{ATP}$ and $0.2 \mathrm{mM}$ NAD with (hatched bars) or without (solid bars) $15 \mu \mathrm{g} / \mathrm{ml}$ of pertussis toxin before adding thrombin $(0.2 \mu \mathrm{M})$ or $\mathrm{U} 46619(10 \mu \mathrm{M})$. [ ${ }^{32} \mathrm{P}$ ]phosphatidic acid formation was measured $3 \mathrm{~min}$ later. The results shown are the mean \pm standard error of the mean of four studies. In the lower half of the figure the time course of CAMP formation is shown in platelets stimulated with $1 \mu \mathrm{M} \mathrm{PGI}_{2}$. Intact platelets were preincubated for $15 \mathrm{~s}$ with buffer (closed circles), $0.2 \mu \mathrm{M}$ thrombin $(X)$, or $10 \mu \mathrm{M}$ U46619 (open circles) before the addition of the $\mathrm{PGI}_{2}$. The amount of cAMP present in the cells was measured 30,60 , and $120 \mathrm{~s}$ after the $\mathrm{PGI}_{2}$ was added. The results shown are the mean of three studies.

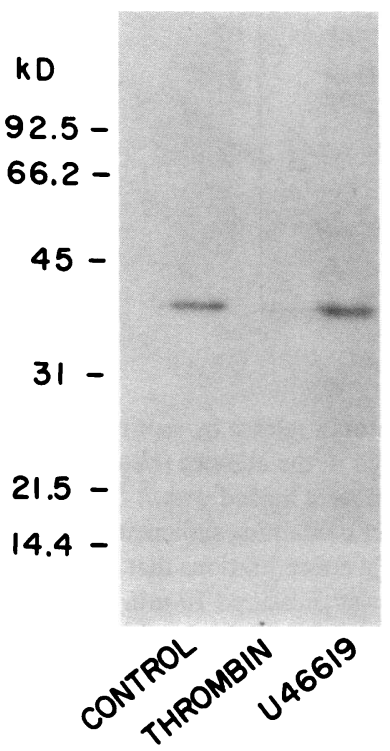

Figure 4. Inhibition of ADP ribosylation by thrombin and $\mathrm{U} 46619$. Washed platelets were preincubated with or without thrombin (1 $\mathrm{U} / \mathrm{ml})$ for $5 \mathrm{~s}$ or $\mathrm{U} 46619(10 \mu \mathrm{M})$ for $15 \mathrm{~s}$ before adding saponin (15 $\mu \mathrm{g} / \mathrm{ml})$, NAD $(50 \mu \mathrm{M}),\left[{ }^{32} \mathrm{P}\right]$ NAD and EGTA $(10 \mu \mathrm{M})$. After an additional $30 \mathrm{~min}$, the platelets were sedimented and then analyzed by polyacrylamide electrophoresis. The figure shows an autoradiogram of the ${ }^{32}$ P-labeled proteins. Variations in the intensity of labeling were confirmed by densitometry. 


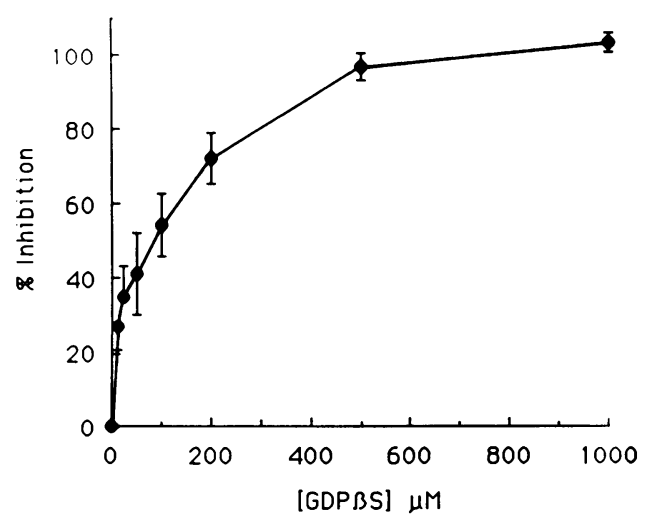

Figure 5. Effect of GDP $\beta S$ on $\mathrm{IP}_{3}$-induced serotonin release. $\left[{ }^{14} \mathrm{C}\right]$ serotonin-loaded platelets were preincubated with saponin and GDP $\beta S$ (final concentration shown) for 1 min before adding $\mathrm{IP}_{3}$ (40 $\mu \mathrm{M})$. Secretion was measured $5 \mathrm{~min}$ later. The results shown are expressed as the \% inhibition of the results obtained with $\mathrm{IP}_{3}$ alone and are the mean \pm standard error of the mean of four studies.

GDP $\beta$ S has no effect on secretion caused by the diacylglycerol analogue 1-oleoyl-2-acetyl-glycerol (OAG) or on $\mathrm{Ca}$ release in response to $\mathrm{IP}_{3}(26)$. Taken together, these observations suggest that effects of GDP $\beta$ S are on phosphoinositide hydrolysis and not on the secretory mechanism initiated by newly-formed diacylglycerol.
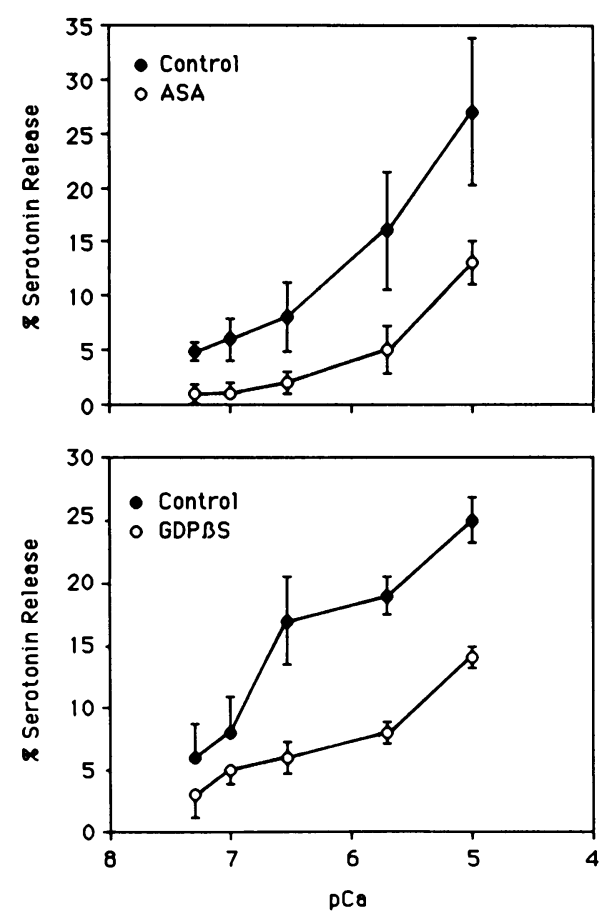

Figure 6. Inhibition of Ca-induced serotonin release by aspirin and GDPBS. (Top) Washed platelets prepared in the absence (closed circles) or presence (open circles) of aspirin were loaded with $\left[{ }^{14} \mathrm{C}\right]$ serotonin and resuspended in buffer containing sufficient EGTA or $\mathrm{CaCl}_{2}$ to give the approximate free $\mathrm{Ca}$ concentrations that are shown. The extent of serotonin release was measured $10 \mathrm{~min}$ after the addition of saponin. The results shown are the mean \pm standard error of the mean of three studies. (Bottom) GDPBS ( $3 \mathrm{mM}$ ) was added to the platelets at the same time as the saponin. Mean \pm standard error of the mean of four studies.
If, as is suggested by these data, agonist-mediated phosphoinositide hydrolysis can cause secretion either directly via diacylglycerol or indirectly via $\mathrm{IP}_{3} / \mathrm{Ca}$-stimulated arachidonic acid metabolism, then the effects of aspirin on agonist-induced secretion might be expected to vary with the strength of the initial stimulus for phosphoinositide hydrolysis. This is known to be the case for thrombin. However, in the case of thrombin, there is also evidence that secretion can occur in the absence of phosphoinositide hydrolysis (26). Therefore, in order to have as specific a stimulus for $G$ protein-mediated phosphoinositide hydrolysis as possible, we examined the effects of aspirin on secretion caused by the nonhydrolyzable GTP analogue, Gpp(NH)p. As is shown in Fig. 7, at low Gpp(NH)p concentrations serotonin release was markedly inhibited by aspirin. At higher $\mathrm{Gpp}(\mathrm{NH}) \mathrm{p}$ concentrations, however, maximal secretion occurred despite the aspirin.

\section{Discussion}

There is now good evidence in platelets that phospholipase $\mathrm{C}$ is coupled to thrombin receptors by $\mathrm{a} G$ protein. Studies from this laboratory suggest that the $\alpha$ subunit of this G protein has a molecular mass of $\sim 42 \mathrm{kD}$ and is a substrate for pertussis toxin (26). Based upon similar types of evidence, it appears that a G protein, commonly referred to as $G_{p}$, is also responsible for phospholipase $\mathrm{C}$ activation in an ever-growing list of tissues, including insect salivary glands, mast cells, neutrophils, adipocytes, and hepatocytes (31-35). To date, $G_{p}$ has been characterized functionally, but has not been isolated. Adding to the uncertainties about the properties of $G_{p}$ is the observation that in some tissues, including platelets, neutrophils, HL-60 cells, and mast cells, agonist or hormone-induced phosphoinositide hydrolysis is inhibited by pertussis toxin, whereas in other tissues it is not. This difference does not appear to be due to differences in the ability of the pertussis toxin to enter cells. In several of the cases in which it was not possible to demonstrate inhibition of phosphoinositide hydrolysis, it was possible to demonstrate other effects of the toxin, such as ADP ribosylation of $G_{i}$.

It has recently been shown that platelets have specific, highaffinity receptors for $\mathrm{TxA}_{2} / \mathrm{PGH}_{2}$ analogues (20). Although the precise location of these receptors has yet to be determined, the available data suggest that they are located on the platelet surface. Two pieces of evidence suggest that these receptors are also coupled to phospholipase $\mathrm{C}$ by a $\mathrm{G}$ protein. First, Houslay and co-

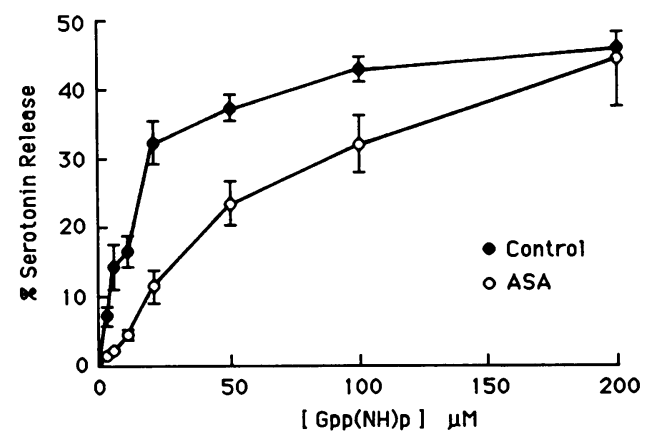

Figure 7. Effect of aspirin on Gpp(NH)p-induced secretion. Washed platelets prepared in the absence (solid symbols) or presence (open symbols) of aspirin were loaded with $\left[{ }^{14} \mathrm{C}\right]$ serotonin and preincubated with saponin for $2 \mathrm{~min}$ before the addition of $\mathrm{Gpp}(\mathrm{NH}) \mathrm{p}$. The results shown are the mean \pm standard error of the mean of five studies. 


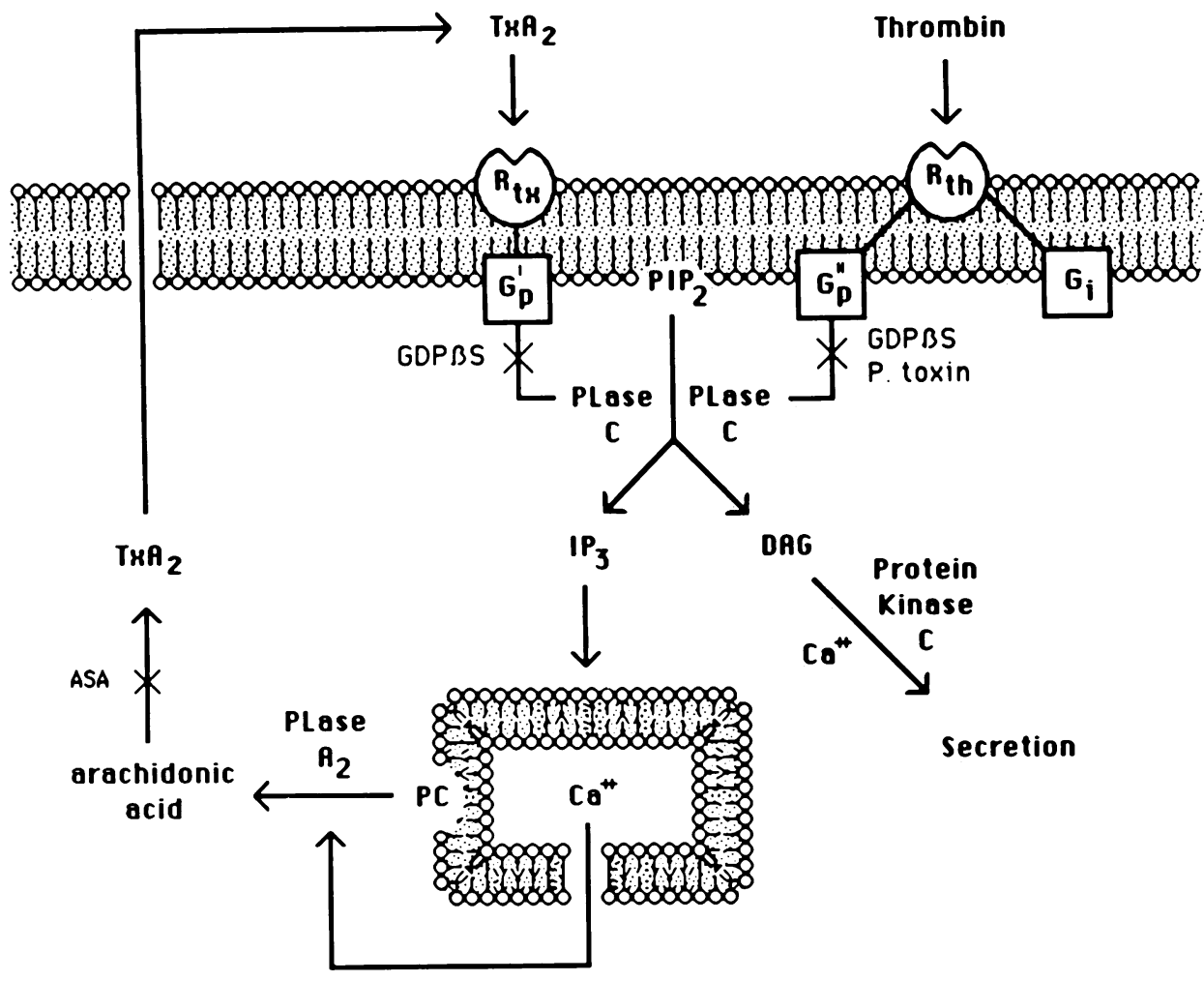

Figure 8. A scheme for the interaction between the phosphoinositide and arachidonic acid pathways during platelet activation. The shaded band at the top represents the platelet plasma membrane. The dense tubular system is shown at the bottom. The receptor abbreviation $\left(R_{t h}\right.$ and $\left.R_{t x}\right)$ represent the receptors for thrombin and $\mathrm{TxA}_{2}$ linked to phospholipase C (PLase $C$ ) by guanine nucleotide-dependent regulatory proteins $\left(G_{p}\right.$ and $\left.G_{p}^{\prime \prime}\right) . \mathrm{G}_{\mathrm{i}}$, protein that mediates inhibition of adenylate cyclase; $\mathrm{IP}_{3}$, inositol 1,4,5-triphosphate; PIP $_{2}$, phosphatidylinositol 4,5-bisphosphate; DAG, diacylglycerol; AA, arachidonic acid formed from phosphatidylcholine $(P C)$ among other sources. The proposed sites of inhibition by aspirin $(A S A)$, pertussis toxin (P. Toxin) and GDP $\beta$ S are shown. workers (31) have shown that endoperoxide analogues stimulate GTPase activity in platelet membranes. Second, the present studies show that GDP $\beta$ S completely inhibits U46619-induced diacylglycerol formation and secretion. The concentration of GDP $\beta S$ required is similar to that which inhibits thrombin-induced phosphoinositide hydrolysis and $\mathrm{PGI}_{2}$-stimulated cAMP formation in permeabilized platelets (26). Up to this point these results parallel those obtained with thrombin. In contrast to thrombin, however, the ability of U46619 to stimulate phosphatidic acid formation was unaffected by pertussis toxin, an observation in agreement with Houslay's (31) finding that endoperoxide-stimulated GTPase activity in platelet membranes is unaffected by pertussis toxin.

In order to address this issue further, we also compared the ability of thrombin and $\mathrm{U} 46619$ to cause inhibition of $\mathrm{PGI}_{2-}$ stimulated CAMP formation, a process known to involve the pertussis toxin-sensitive $G$ protein, $G_{i}$. Thrombin inhibited cAMP formation. U46619 did not. ${ }^{2}$ Further evidence that the $\mathrm{G}$ protein(s) coupled to platelet thromboxane receptors are not sensitive to pertussis toxin was obtained by examining the effect of $\mathrm{U} 46619$ on the $\left[{ }^{32} \mathrm{P}\right] \mathrm{ADP}$ ribosylation of the single $42-\mathrm{kD}$ pertussis toxin substrate found in platelets. Thrombin, which has toxin-sensitive effects on both phosphoinositide hydrolysis and CAMP formation, completely inhibits labeling of this protein

2. The literature contains conflicting reports on the ability of arachidonic acid metabolites to inhibit PGE $_{1}$-stimulated cAMP formation. An earlier report by Miller et al. (36) suggested that platelet endoperoxides can in fact inhibit cAMP formation. However, those studies, in contrast to the present studies and those of Best et al. (37), were performed using stirred platelets in plasma at $37^{\circ} \mathrm{C}$, conditions in which platelet aggregates were formed. Under these circumstances, released ADP, not $\mathrm{TxA}_{2}$, may have mediated the suppression of adenylate cyclase.
(26). Based upon studies performed with the well-characterized adenylate cyclase regulatory system, this appears to be due to the ability of thrombin to dissociate the heterotrimeric $\mathrm{G}$ proteins coupled to thrombin receptors into $\beta / \gamma$ dimers and free $\alpha$ subunits which are no longer substrates for the toxin (38). We found that U46619 had no effect on $\mathrm{PGI}_{2}$-stimulated cAMP formation and caused toxin-insensitive phosphoinositide hydrolysis and, in contrast to thrombin, U46619 had no effect on the $\left[{ }^{32} \mathrm{P}\right] \mathrm{ADP}$ ribosylation of the $42-\mathrm{kD}$ protein.

It is not immediately obvious why within a single tissue the $G$ protein responsible for the same set of responses to different agonists should be affected by pertussis toxin in some cases, but not in others-yet this appears to be the case in platelets. It may also be the case in hepatocytes where Johnson and co-workers (39) have recently reported that pertussis toxin inhibits phospholipase $\mathrm{C}$ activation by epidermal growth factor but not by angiotensin II. It is also not clear why the function associated with $G_{p}$ should be sensitive to pertussis toxin in some tissues, but not others. $G_{p}$ has yet to be isolated from any tissue in which there is functional evidence for its existence. The sole identifiable pertussis toxin substrate in platelets co-migrates on SDS gels with the $\alpha$ subunit of $G_{i}$. Two recent studies have shown that hormone-stimulated phosphoinositide hydrolysis can be restored in pertussis toxin-treated membranes with HL-60 cells and neutrophils by adding back purified $G_{i}(40,41)$. In one of the studies, phosphoinositide hydrolysis was also restored by $G_{0}$, a wellcharacterized $G$ protein from brain whose function has yet to be determined. One possible explanation for these observations is that the role and the toxin-sensitivity of $G$ proteins may depend in part upon the characteristics of the receptor to which the $G$ protein is coupled. This remains to be determined.

Feedback amplification of phosphoinositide hydrolysis. The second issue that was addressed in the present studies is the 
mechanism by which $\mathrm{IP}_{3}$ causes secretion in platelets. The data obtained are consistent with a model in which $\mathrm{IP}_{3}$ causes secretion by an "indirect" pathway in which the Ca released from the dense tubular system activates phospholipase $A_{2}$, initiating the arachidonic acid pathway which, in turn, stimulates receptorlinked, guanine nucleotide-regulated phosphoinositide hydrolysis leading to diacylglycerol formation and, finally, granule secretion. Specifically, our data, in combination with those of previous investigators show: $(a)$ that $\mathrm{IP}_{3}$-induced serotonin release, but not $\mathrm{IP}_{3}$-induced $\mathrm{Ca}$ release, is inhibited by aspirin, $\mathrm{TxA}_{2}$ antagonists, and GDP $\beta S$ and $(b)$ that Ca-induced secretion is also inhibited by aspirin and GDP $\beta S$. The effect of GDP $\beta S$ in this case appears to be confined to inhibition of phosphoinositide hydrolysis because GDP $\beta S$ was found to inhibit neither $\mathrm{IP}_{3}$ induced $\mathrm{Ca}$ release nor secretion in response to the synthetic diacylglycerol, OAG. These observations are incorporated into the model shown in Fig. 8. In this model positive feedback from the phosphoinositide hydrolysis pathway through the arachidonic acid pathway causes further phosphoinositide hydrolysis by stimulating platelet thromboxane receptors. In order to distinguish the toxin-insensitive $G$ protein coupled to $T x A_{2}$ receptors from the toxin-sensitive $G$ protein coupled to thrombin receptors, the former is identified as $G_{p}^{\prime}$ and the latter as $G_{p}^{\prime \prime}$ in Fig. 8.

In a platelet maximally stimulated with high concentrations of an agonist such as thrombin, such feedback is probably superfluous. However, with low concentrations of thrombin or with agonists that are weaker stimuli for phosphoinositide hydrolysis or with agonists, such as epinephrine, which do not appear to have a primary effect on phosphoinositide hydrolysis $(42,43)$, this pathway may serve to reinforce platelet activation. In fact, in epinephrine-stimulated platelets phosphoinositide hydrolysis appears to be entirely attributable to the activation of phospholipase $A_{2}$ and thromboxane formation (43). In addition, because $\mathrm{TxA}_{2}$ is released from activated platelets, this process, along with ADP released from platelet-dense granules, would provide a mechanism for the recruitment of additional platelets into a growing platelet plug.

\section{Acknowledgments}

This work was supported in part by grants HL-29018 and HL-33852 from the National Institutes of Health and was undertaken during the tenure of an American Heart Association Established Investigator Award to Dr. Brass.

\section{References}

1. Rittenhouse-Simmons, S. 1979. Production of diglyceride from phosphatidylinositol in activated human platelets. J. Clin. Invest. 63: 580-587.

2. Broekmann, J., J. Ward, and A. Marcus. 1980. Phospholipid metabolism in stimulated human platelets. J. Clin. Invest. 66:275-283.

3. Billah, M., and E. Lapetina. 1982. Rapid decrease of phosphatidylinositol 4,5-bisphosphate in trombin-stimulated platelets. J. Biol. Chem. 257:12705-12708.

4. Agranoff, B., P. Murthy, and E. Seguin. 1983. Thrombin-induced phosphodiesteratic cleavage of phosphatidylinositol bisphosphate in human platelets. J. Biol. Chem. 258:2076-2078.

5. Kaibuchi, K., Y. Takai, M. Sawamura, M. Hoshijima, T. Fujikura, and $Y$. Nishizuka. 1983. Synergistic functions of protein phosphorylation and calcium mobilization in platelet activation. J. Biol. Chem. 258:67016704.

6. Lapetina, E., B. Reep, B. Ganong, and R. Bell. 1985. Exogenous sn-1,2-diacylglycerols containing saturated fatty acids function as bio- regulators of protein kinase $C$ in human platelets. J. Biol. Chem. 260: 1358-1361.

7. Shattil, S., and L. Brass. 1987. Induction of the fibrinogen receptor on human platelets by intracellular mediators. J. Biol. Chem. 262:9921000.

8. Brass, L., and S. K. Joseph. 1985. A role for inositol triphosphate in intracellular $\mathrm{Ca}^{2+}$ mobilization and granule secretion in platelets. $J$. Biol. Chem. 260:15172-15179.

9. Lapetina, E., S. Watson, and P. Cuatrecasas. 1984. Myo-inositol 1,4,5-triphosphate stimulates protein phosphorylation in saponin-permeabilized human platelets. Proc. Natl. Acad. Sci. USA 81:7431-7435.

10. Israels, S., P. Robinson, J. Docherty, and J. Gerrard. 1985. Activation of permeabilized platelets by inositol-1,4,5-triphosphate. Thromb. Res. 40:499-509.

11. Authi, K., E. Evenden, and N. Crawford. 1986. Metabolic and functional consequences of introducing inositol 1,4,5-triphosphate into saponin-permeabilized human platelets. Biochem. J. 233:709-718.

12. Watson, S., M. Ruggiero, S. Abrahams, and E. Lapetina. 1986. Inositol 1,4,5-triphosphate induces aggregation and release of 5-hydroxytryptamine from saponin-permeabilized human platelets. J. Biol. Chem. 261:5368-5372.

13. O'Rourke, F., S. Halenda, G. Zavoico, and M. Feinstein. 1985. Inositol 1,4,5-triphosphate releases $\mathrm{Ca}^{2+}$ from $\mathrm{Ca}^{2+}$-transporting membrane vesicle fraction derived from human platelets. J. Biol. Chem. 260: 956-962.

14. Adunyah, S., and W. Dean. 1985. Inositol triphosphate-induced $\mathrm{Ca}^{2+}$ release from human platelet membranes. Biochem. Biophys. Res. Commun. 128:1274-1280.

15. Authi, K., and N. Crawford. 1985. Inositol 1,4,5-triphosphateinduced release of sequestered $\mathrm{Ca}^{2+}$ from highly purified human platelet intracellular membranes. Biochem. J. 230:247-253.

16. Haslam, R., and M. Davidson. 1984. Guanine nucleotides decrease the free $\mathrm{Ca}$ required for secretion of serotonin from permeabilized blood platelets. Evidence of a role for a GTP-binding protein in platelet activation. FEBS (Fed. Eur. Biochem. Soc.) Lett. 174:90-95.

17. Haslam, R., and M. Davidson. 1984. Receptor-induced diaglycerol formation in permeabilized platelets; possible role for a GTP-binding protein. J. Recept. Res. 4:605-629.

18. Knight, D., and M. Scrutton. 1985. Effect of various excitatory agonists on the secretion of 5-hydroxytryptamine from permeabilised human platelets induced by $\mathrm{Ca}^{2+}$ in the presence or absence of GTP. FEBS (Fed. Eur. Biochem. Soc.) Lett. 183:417-422.

19. Brass, L., C. Shaller, and E. Belmonte. 1985. Dual pathways for intracellular $\mathrm{Ca}$ mobilization and granule secretion during thrombininduced platelet activation. Blood. 66:301a. (Abstr.)

20. Saussy, D., D. Mais, R. Burch, and P. Halushka. 1986. Identification of a putative thromboxane $\mathrm{A}_{2}$ /prostaglandin $\mathrm{H}_{2}$ receptor in human platelet membranes. J. Biol. Chem. 261:3025-3029.

21. Siess, W., B. Boehlig, P. Weber, and E. Lapetina. 1985. Prostaglandin endoperoxide analogues stimulate phospholipase $C$ and protein phosphorylation during platelet shape change. Blood. 65:1141-1148.

22. Rittenhouse, S. 1984. Activation of human platelet phospholipase C by ionophore A23187 is totally dependent upon cyclo-oxygenase products and ADP. Biochem. J. 222:103-110.

23. Pollock, W., R. Armstrong, L. Brydon, R. Jones, and D. MacIntyre. 1984. Thromboxane-induced phosphatidate formation in human platelets. Biochem. J. 219:833-842.

24. Loeb, L., and R. Gross. 1986. Identification and purification of sheep platelet phospholipase $A_{2}$ isoforms. J. Biol. Chem. 261:1046710470.

25. Houslay, M., D. Bojanic, D. Gawler, S. O'Hagen, and W. Wilson. 1986. Thrombin, unlike vasopressin, appears to stimulate two distinct guanine nucleotide regulatory proteins in human platelets. Biochem. J. 238:109-113.

26. Brass, L., M. Laposata, H. Banga, and S. Rittenhouse. 1986. Regulation of the phosphoinositide hydrolysis pathway in thrombinstimulated platelets by a pertussis toxin-sensitive guanine nucleotide binding protein. J. Biol. Chem. 261:16838-16847. 
27. Kikuchi, A., O. Kozawa, K. Kaibuchi, T. Katada, M. Ui, and Y. Takai. 1986. Direct evidence for a guanine nucleotide-binding protein in chemotactic peptide-stimulated formation of inositol bisphosphate and trisphosphate in differentiated human leukemic (HL-60) cells. $J$. Biol. Chem. 261:11558-11562.

28. Okajima, F., T. Katada, and M. Ui. 1985. Coupling of the guanine nucleotide regulatory protein to chemotactic peptide receptors in neutrophil membranes and its uncoupling by islet-activating protein, pertussis toxin. J. Biol. Chem. 260:6761-6768.

29. Brass, L., and S. Shattil. 1987. The interaction of extracellular Ca with the surface membrane of human platelets. Methods Enzymol. In press.

30. Siess, W., P. Cuatrecasas, and E. Lapetina. 1983. A role for cyclooxygenase products in the formation of phosphatidic acid in stimulated human platelets. J. Biol. Chem. 258:4683-4686.

31. Houslay, M., D. Bojanic, and A. Wilson. 1986. Platelet activating factor and U44069 stimulate a GTPase activity in human platelets which is distinct from the guanine nucleotide regulatory proteins. Biochem. $J$. 234:737-740.

32. Gomperts, B. 1983. Involvement of guanine nucleotide-binding protein in the gating of $\mathrm{Ca}^{2+}$ by receptors. Nature (Lond.). 306:64-66.

33. Nakamura, T., and M. Ui. 1985. Simultaneous inhibitions of inositol phospholipid breakdown, arachidonic acid release, and histamine secretion in mast cells by islet-activating protein, pertussis toxin. J. Biol. Chem. 260:3584-3593.

34. Molski, T., P. Naccache, M. Marsh, J. Kermode, E. Becker, and R. Sha afi. 1984. Pertussis toxin inhibits the rise in the intracellular concentration of free calcium that is induced by chemotactic factors in rabbit neutrophils: possible role of the "G proteins" in calcium mobilization. Biochem. Biophys. Res. Commun. 124:644-650.

35. Okajima, F., and M. Ui. 1984. ADP-ribosylation of the specific membrane protein by islet-activating protein, pertussis toxin, associated with inhibition of a chemotactic peptide-induced arachidonate release in neutrophils. J. Biol. Chem. 259:13863-13871.

36. Miller, O., R. Johnson, and R. Gorman. 1977. Inhibition of PGE $_{1}$-stimulated cAMP accumulation in human platelets by thromboxane $A_{2}$. Prostaglandins. 13:599-609.

37. Best, L., M. McGuire, T. Martin, F. Preston, and R. Russell. 1979. Effects of epoxymethane analogues of prostaglandin endoperoxides on aggregation, on release of 5-hydroxytryptamine and on the metabolism of 3',5'-cyclic AMP and cyclic GMP in human platelets. Biochim. Biophys. Acta. 583:344-351.

38. Katada, T., M. Oinuma, and M. Ui. 1986. Two guanine nucleotide-binding proteins in rat brain serving as the specific substrate of isletactivating protein, pertussis toxin. J. Biol. Chem. 261:8182-8191.

39. Johnson, R., P. Connelly, R. Sisk, B. Pbiner, E. Hewlett, and J. Garrison. 1983. Pertussis toxin or phorbol 12-myristate 13-acetate can distinguish between epidermal growth factor- and angiotensin-stimulated signals in hepatocytes. Proc. Natl. Acad. Sci. USA. 83:2032-2036.

40. Eckstein, F., D. Cassel, H. Levkovitz, M. Lowe, and Z. Selinger. 1979. GDP $\beta$ S: an inhibitor of adenylate cyclase stimulation by guanine nucleotides and fluoride ions. J. Biol. Chem. 254:9829-9834.

41. Jakobs, K. 1983. Determination of the turn-off reaction for the epinephrine-inhibited human platelet adenylate cyclase. Eur. J. Biochem. 132:125-130.

42. Siess, W., P. Weber, and E. Lapetina. 1984. Activation of phospholipase $\mathrm{C}$ is dissociated from arachidonate metabolism during platelet shape change induced by thrombin or platelet-activating factor. J. Biol. Chem. 259:8286-8292.

43. Singh, H., E. Simons, L. Brass, and S. Rittenhouse. 1983. Activation of phospholipases $A$ and $C$ in human platelets exposed to epinephrine: the role of glycoproteins IIb/IIIa and the dual role of epinephrine. Proc. Natl. Acad. Sci. USA. 83:9197-9201. 